\title{
Diffusion and the choice of democratic government system at the time of democratisation
}

\author{
Jenny Åberg (1) - Thomas Denk (i)
}

Published online: 26 May 2020

(C) The Author(s) 2020

\begin{abstract}
While significant research has been conducted on both the diffusion of democracy and the various democratic government systems (parliamentary, presidential and semi-presidential), the diffusion of individual democratic government systems has rarely been addressed. Therefore, this article examines whether diffusion explains why countries have established different types of government systems at the time of democratisation. Previous studies on democratic regime types have found that the establishment of democratic government systems is spatially and temporally clustered, which could indicate that democratic regime types are diffused. Inspired by diffusion studies, we test the hypothesis that the density of a particular democratic government system in a network positively affects the probability that a country in that network established the same form of democratic government system at the time of democratisation. We test this assumption through empirical analysis, using 121 cases of democratisation in which a democratic system of government was established at the time of independence or after a period of autocracy. Using logistic regression, this paper explores the connection between the choice of government system at the time of democratisation and the composition of democratic government systems in seven networks of countries: geographic neighbourhood, regional, continental, global, cultural, post-colonial and post-autocratic. The results indicate empirical support for our hypothesis; therefore, we conclude that the choice of government system at the time of democratisation is influenced by conditions in other countries.
\end{abstract}

\footnotetext{
J. Åberg $(\bowtie)$

Dalarna University, Högskolegatan 2, 79188 Falun, Sweden

E-Mail: jae@du.se

T. Denk

Örebro University, Fakultetsgatan 1, 70182 Örebro, Sweden
} 
Keywords Political regime - Democratisation · Democratic diffusion · Constitutional choice

\section{Diffusion und die Wahl eines demokratischen Regierungssystems zum Zeitpunkt der Demokratisierung}

Zusammenfassung Obwohl bedeutende Forschungsarbeiten sowohl zur Verbreitung von Demokratie als auch zum Verständnis verschiedener demokratischer Regierungssysteme (parlamentarisch, präsidentiell und semi-präsidentiell) publiziert wurden, spielte die Diffusion einzelner demokratischer Regierungssysteme selten eine größere Rolle. In diesem Artikel wird daher untersucht, ob die Diffusionstheorie erklärt, warum Länder verschiedene Arten von Regierungssystemen zur Zeit der Demokratisierung etablierten. Bisherige Studien über demokratische Regimetypen zeigen, dass die Etablierung demokratischer Regierungssysteme räumlich und zeitlich gebündelt ist, was darauf hinweisen könnte, dass demokratische Regimetypen per Diffusion entstanden sind. Inspiriert durch die Diffusionsforschung testen wir die Hypothese, dass die Häufigkeit eines bestimmten demokratischen Regierungssystems in einem Netzwerk die Wahrscheinlichkeit positiv beeinflusst, dass ein Land in diesem Netzwerk das gleiche demokratische Regierungssystem zum Zeitpunkt der Demokratisierung wählt. Wir überprüfen diese Annahme durch eine empirische Analyse anhand von 121 Fällen, in der ein demokratisches Regierungssystem zum Zeitpunkt der Unabhängigkeit oder nach dem Ende einer Autokratie entstanden ist. Mittels logistischer Regressionen untersucht die Studie den Zusammenhang zwischen der Wahl des Regierungssystems zum Zeitpunkt der Demokratisierung und der Zusammensetzung der demokratischen Regierungssysteme in sieben Netzwerken: geographische Nachbarschaft, regional, kontinental, global, kulturell, postkolonial und postautokratisch. Die empirischen Ergebnisse stützen unsere Hypothese, so dass wir zu dem Schluss kommen, dass die Wahl des Regierungssystems zum Zeitpunkt der Demokratisierung von den Bedingungen in anderen Ländern beeinflusst wird.

Schlüsselwörter Politisches Regime - Demokratisierung · Diffusionstheorie · Regierungssystem

\section{Introduction}

At the time of democratisation, countries establish a new type of government system (Gunitsky 2014; Jung and Deering 2015). While some countries opt for a parliamentary system $(42 \%)$, others choose presidential $(38 \%)$ or semi-presidential systems (20\%). Research on democratic government systems has tried to explain this variation but, despite evidence of spatial and temporal clustering, studies have largely ignored diffusion as a potential explanation for systemic variation at the time of democratisation. The few studies that have considered diffusional effects fail to reflect recent developments in the field of democratic diffusion, as they focus solely on neighbourhood diffusion (Jung and Deering 2015). The aim of this article is, there- 
fore, to empirically examine whether diffusion explains why countries establish different types of democratic government systems at the time of democratisation.

To achieve this aim, we examine the potential influence of diffusion on government system choice in 121 cases of democratisation (1946-2008). Our analysis indicates that diffusion, through various overlapping networks, has strong effects on the choice of democratic government system. We conclude that, to a significant degree, diffusion explains the choice of democratic government system at the time of democratisation. Forms of democratic government systems spread between countries through various international networks. These findings contribute to the field of democratic diffusion-which has largely overlooked the spread of specific forms of democratic government systems - and the research on the choice of democratic government system, which has, thus far, primarily focused on domestic explanations.

This article proceeds as follows. The next two sections present the concepts of democratisation, democratic systems of government, and democratic diffusion. The fourth section develops the theoretical argument for the diffusion of democratic systems of government at the time of democratisation. The fifth section discusses the research design, measurements and control variables used. The sixth section presents the empirical results and connects them to our hypothesis. The concluding section summarises the results, answers the primary research question-does diffusion explain the varying choices of democratic government systems at the time of democratisation? - and discusses the importance of our findings for future studies.

\section{Democratisation and democratic systems of government}

This article aims to examine whether diffusion explains the variation in choice of democratic government system at the time of democratisation, which is the period during which a country establishes democratic institutions. Since 1800, two significant processes have established democratic regimes (Denk and Lehtinen 2016). The first of these, a democratic transition, replaces autocratic institutions with democratic institutions (Carothers 2002). The second process, state formation, occurs when a democratic regime is established at the time of independence (Denk and Lehtinen 2019). In contrast to the many studies that only focus on democratic transition, we consider cases of democratisation through state formation as well-the choice of democratic system is a crucial outcome of both processes.

Regardless of the process, however, complete democratisation requires the establishment of democratic institutions. A key part of this institutional setup is the distribution of political power. While autocratic regimes tend to concentrate power in a single actor or institution, democracies allocate power among various government institutions. One of the most critical choices concerns the executive-legislative power distribution. At the time of democratisation, political elites must determine how to distribute state power (Cheibub 2007; Lijphart 1992; Linz 1990; Mainwaring and Shugart 1997; Sartori 1997). One option is to apply the principle of checks and balances and require the direct election of both a president and legislature, thereby creating a presidential regime, in which political functions are distributed between legislative, executive and judicial institutions with each having the ability to regu- 
late or moderate the others. The second option entails concentrating power in the legislative branch, holding direct elections for the legislature only and making the government dependent on the legislature's support. If there is also limited judicial control and the head of state has a largely ceremonial function, the system constitutes a parliamentary regime. The third option is to pair a directly elected president with a government (and prime minister) responsible to the legislature (Elgie 2011). This constitutes a semi-presidential regime, also referred to as a mixed form of democracy (Cheibub et al. 2010). Presidential, parliamentary and semi-presidential regimes comprise the various democratic systems of government, in which executive-legislative functions are distributed differently. Political actors establish one of these three types of democratic government system at the time of democratisation; as stated, our aim is to examine whether external diffusion affects the choice.

Studies on democratic systems of government have emphasised endogenous (domestic) conditions as the primary factors behind the systemic variation among countries (Jung and Deering 2015; Mainwaring and Shugart 1997; Persson and Tabellini 2003). For example, Frye (1997, p. 532) studies the selection of powers invested in the president as an outcome of elite actor negotiations in which elites aim to maximise their future power 'by designing institutions that will allow them to exercise their power to the greatest extent possible'. Uncertainty in the decision-making process, however, may obstruct their ability to calculate their future position in the institutional arrangement. High levels of uncertainty are expected to induce riskaverse solutions, or institutions that spread, rather than concentrate, political power. Jung and Deering (2015) illustrate this approach by showing that historical and geographical conditions affect the choice of democratic government system alongside the negotiations between old and new elites. They conclude that parliamentary systems are more likely to be established during periods of high uncertainty while presidential systems tend to be more likely during periods of low uncertainty. Their analysis includes a diffusion variable that measures how government types diffuse between neighbouring countries. Neighbourhood diffusion is, however, just one type of diffusion according to research on democratic diffusion.

\section{Diffusion of democratic systems}

Research on democratic diffusion assumes that political systems tend to be susceptible to foreign influence. As Houle et al. (2015) point out, democratic transitions have occurred in spatial and temporal clusters. Shifts from autocratic to democratic regimes tend to take place in several countries in the same region at the same time. Studies have looked to diffusion as a potential explanation for these spatial and temporal patterns. Initial studies treated instances of diffusion as regional or neighbourhood effects (Starr 1991) while others focused on diffusion at the global level, arguing that a higher overall number of democratic regimes results in higher numbers of new democracies (Huntington 1991; Gleditsch and Ward 2006). O'Loughlin et al. (1998) further developed democratic diffusion research by examining temporal and spatial democratic diffusion within regions. Later research has accordingly shown that democratisation tends to spread through established relations between coun- 
tries that belong to the same cultural, economic or political networks (Beck et al. 2006; Teorell 2010; Wejnert 2005; Weyland 2014). These results challenge previous models, which emphasised the significance of geographical proximity. Houle et al. (2015) show that, with few exceptions, studies have found empirical support for democratic diffusion. This diffusion appears to occur across various types of country networks.

In order to explain the empirical results, studies on diffusion have developed theoretical understandings on how different mechanisms of diffusion operate (Brinks and Coppedge 2006; Houle et al. 2015; Lijphart 1990; Wejnert 2005; Weyland 2014). Prominent in the literature are the four mechanisms of Simmon, Dobbin and Garrett (2006), which capture how policies in one country affect those made later in other countries. They argue that diffusion can evolve through implicit or explicit pressure of more powerful countries on less powerful ones (coercion). Diffusion may also arise from competition between countries, as new policies can increase the efficiency or attractiveness of a system (competition). Diffusion may, however, also come from 'simple learning' through new information, success-or-failure stories from other countries, and new beliefs on what is worth being pursued (learning). Whether it stems from a global change in what is deemed acceptable or from the influence of 'self-identified peers', diffusion may also come through a change in norms (emulation). Aside from these four mechanisms, diffusion may also evolve from demonstration and contagion effects stemming from ground-breaking events or decisions in other countries (Wejnert 2014; Weyland 2014). Diffusion can evidently occur for various reasons and through various mechanisms.

While studies have identified these mechanisms, how they apply has yet to be thoroughly disentangled (Simmon et al. 2006; Weyland 2014). However, since diffusion is interpreted as a social process that evolves through particular channels (Rogers 2005), various types of international networks have been treated as vessels within which the mechanisms of diffusion evolve (Braun and Gilardi 2006; Maggetti and Gilardi 2016; Weyland 2014). Networks facilitate temporally stable patterns of interaction and establish new channels of communication among their members (Hedström 2010). This is important, as diffusion presupposes communication between actors (Rogers 2005). With stable interaction among network members, norms defining appropriate behaviour may spread, including views on democratisation among elites. Networks may, therefore, incorporate several of the diffusion mechanisms presented above.

Studies build on theoretical assumptions about diffusion through network interactions, so the question of which networks are relevant for democratic diffusion is both crucial and controversial. Previous studies have generally included six types of networks.

First, geographical networks at various levels have dominated in research on democratic diffusion. Early studies assumed that geographical proximity fosters interaction and promotes diffusion over time between neighbouring countries (Brinks and Coppedge 2006; Doorenspleet 2005; Gleditsch and Ward 2006; Kopstein and Reilly 2000; Teorell 2010). Later studies have emphasised that political similarities between geographically close countries promote diffusion and have included both socio-political regions and geographic continents as networks in their studies (Bunce 
and Wolchik 2000; Gassebner et al. 2013; Leeson and Dean 2009; O'Loughlin et al. 1998; Wejnert 2014).

Second, studies have claimed that global communication and organisational networks spread ideas and norms between countries. These studies assume that the development of modern communication technology has made the global diffusion of democratic ideas more likely as the global proportion of democracies increases (Brinks and Coppedge 2006; Gleditsch and Ward 2006; Starr and Lindborg 2003; Torfason and Ingram 2010; Wejnert 2005, 2014).

Third, later studies have argued for the importance of transaction networks. These studies assume that connectivity is a function of political and economic transactions. When countries engage in trade, for example, they interact in a way that promotes the spread of political ideas (Beck et al. 2006).

Fourth, some studies have emphasised diffusion through cultural networks, in which a shared language, religion or ethnicity fosters cultural closeness between countries. This cultural proximity promotes a shared identity that facilitates the spread of information and ideas among network members (Lijphart 1990; Weyland 2014). The idea of cultural proximity as a condition for diffusion resembles the theory on homophily that claims culturally similar elites tend to prefer to interact with one another, increasing the level of horizontal diffusion between countries (Rogers 2005).

Fifth, post-colonial networks are those in which shared historical experiences, languages and religions, as well as an increased level of migration, facilitate the exchange of norms and ideas (Bernhard et al. 2004; Coppedge et al. 2016; Lijphart 1990). Empirical studies have demonstrated that post-colonial networks undergo similar patterns of democratisation and constitutional choice (Amorim Neto and Costa-Lobo 2014; Coppedge et al. 2016; Wejnert 2005).

In a recent article, Goldring and Greitens (2019) introduced a sixth type: postautocratic networks. They present results to support their hypothesis that democratisation in autocratic regimes increases the probability of democratisation in countries with a similar type of autocratic regime. According to their explanation, formerly autocratic countries learn from other post-autocratic regimes how to build and develop democratic institutions in a similar context. Jung and Deering (2015) have argued that the type of former autocratic regime affects the level of uncertainty and institutional heritage. For example, uncertainty in countries that formerly had a military dictatorship is higher than in countries that formerly had a civil dictatorship.

\section{Hypothesis on the diffusion of democratic government systems}

Building on the conclusions of existing research on democratic diffusion, we assume that network interactions facilitate mechanisms of diffusion (i.e., that networks enable the spread of values, norms and ideas about government types between networking countries). Democratic government systems are political regimes that consist of value- and norm-based institutions; as such, we assume that interactions within networks spread ideas about democratic government systems between countries and affect which system actors establish at the time of democratisation. However, these 
processes may not be identical to those that spread the general idea of democratisation - the diffusion of specific democratic systems of government may occur in networks distinct from those that diffuse democratisation. Additionally, studies have shown that the density of democratic regimes in networks affects the general probability of democratisation (Brinks and Coppedge 2006; Gassebner et al. 2013; Gleditsch and Ward 2006; Starr and Lindborg 2003; Teorell 2010; Wejnert 2005, 2014). The density of a democratic regime type is the share of countries in the network that have that particular type. It is fair to think that this phenomenon would hold true for the density of particular regime types (i.e., an increase in density leads to a higher level of exposure to that regime type, which in turn results in a higher probability of diffusion and a higher probability that a country in the same network would establish that regime type when it democratises). This gives us theoretical grounds to formulate the following hypothesis:

The density of a democratic system of government in a network positively affects the probability of the establishment of that system in another country within the network at the time of democratisation.

Democratisation plays out at a critical juncture in which actors must make decisions about political institutions that often do not exist yet. These actors must typically make these enormously consequential decisions in a context of uncertainty (Frye 1997; Geddes 1996). Our hypothesis builds on the assumption that the probability of establishing a government system for dealing with political uncertainty increases with the prevalence of this government system in the same network. Uncertainty implies that political institutions, cultural norms and rational models have lost their ability to guide actors, making decisions less predictable. In response to this dynamic, political actors develop strategies to deal with uncertainty. One strategy is to take inspiration from domestic legacies. According to heritage theories, actors may use historical legacies as their point of reference and use historical choices as a guide (Pop-Eleches 2007; Simpser et al. 2018). An alternative theory, which our diffusion hypothesis builds on, is that at the uncertainty of the critical juncture, actors instead turn to their international networks. Communication processes enable actors to learn from experiences within their networks and reform their ideas of what constitutes a 'good' institution. Through rational learning, actors update their information on alternative strategies or solutions by looking at situations in other countries. Bounded rationality focuses on cognitive shortcuts (i.e., representativeness or availability of relevant experiences) where the actors use heuristics from other countries to guide their decision-making (Braun and Gilardi 2006; Simmon et al. 2006; Weyland, 2014).

In sum, we build upon the two-step model introduced by Houle et al. (2015) by proposing a three-step model of democratisation. We argue that democratisation occurs in three steps: (1) the breakdown of the autocratic regime or the establishment of a new state; (2) the introduction of democratic institutions; and (3) the establishment of a particular type of government system, which share political power between political and democratic institutions. The diffusion processes may be similar across the three phases, but the points of reference and the actors are likely to be different. These steps concern various institutional changes that require different 
points of reference for guidance or inspiration. Furthermore, the first two steps may be brought about by mass mobilisation; the third step is more elite-driven (Jung and Deering 2015; Rost and Booth 2008). Diffusion in the third step, therefore, focuses on political elites rather than on citizens.

\section{Measurements, materials and research design}

To test our hypothesis on democratic government system diffusion, we examined the effects of government system density within networks. We collected data on 121 cases of democratisation upon independence or political transition. Our analysis is restricted to the time of democratisation, so it excludes cases in which government systems were adopted before or after democratisation. To measure the type of democratic government systems at the time of democratisation, we used material from the Democracy and Dictatorship database (Alvarez et al. 1996; Cheibub et al. 2010). ${ }^{1}$ This database covers 1946-2008, an intensive period of democratic transition and state formation (Denk and Lehtinen 2016, 2019), and offers information about the political regimes in all independent states. It categorises democratic regimes according to the relationship between its executive and legislative branches, focusing on whether the legislature can remove the government. In presidential systems, the parliament is unable to remove the government ${ }^{2}$ in parliamentary systems, it is able (e.g., through a vote of no-confidence, early elections, change of parliamentary composition) to remove the government. Semi-presidential systems have a popularly elected president with a fixed term, as in presidential systems, but the assembly can remove the government. While there are other significant aspects of the relationship between the executive and the legislature, a focus on the assembly's ability to remove the government and the election of the head of state is sufficient, according to the database, to distinguish between the various democratic systems. In line with Jung and Deering (2015), the data includes three dependent dummy variables that indicate if the outcome of democratisation is a parliamentary, semi-presidential or presidential regime. We have also used Democracy and Dictatorship to measure diffusion variables, which indicate the share of a particular government system in different networks the year before the establishment of a democratic regime.

First, we calculated the share of each democratic government system in networks at the global, continental, regional and neighbourhood level. The global diffusion variable measures the total share of a democratic government system for each year. We also calculated the share of each democratic system at the continental level, with the continents defined as Africa, the Americas, Asia, Europe and Oceania. Moving

\footnotetext{
1 The database measures the time of democratisation as the year in which the country established a democratic system of government through either state formation or democratic transition. Research on democratic diffusion has used the same consideration to analyse the diffusion of democratic institutions. It excludes cases in which government systems were established before or after the democratisation period. We have therefore considered alternative moments of democracy introduction (e.g., introduction of multiparty system or competitive elections). However, these alternatives exclude more cases and includes cases that are not relevant (cases with autocratic regimes).

2 Except through impeachment.
} 
further down, we calculated the share within socio-political regions (see Table 3 for information). This variable indicates regional diffusion and measures the share of a particular democratic system within each region. At the lowest geographical level is a neighbour diffusion variable. To identify neighbouring states, we referred to information from the database Direct Contiguity (version 3.2), which classifies countries as contiguous neighbours if they share land or water borders (up to 24 miles if the states have a 12-mile limit for territorial waters between them) and provides information from 1816 to 2016 (Stinnett et al. 2002). We then calculated the share of democratic government systems among neighbours for each state and year.

Second, to measure diffusion within cultural and post-colonial networks, we applied the percentage of democratic systems among countries that share the same language and religion (for cultural networks) or colonial background (for post-colonial networks) as the target state. Based on Melitz (2008) and information from the CIA World Factbook (2019), we created a variable that identifies groups of countries that have the same official language, a language that the majority of the population speaks, or a global language that at least $10 \%$ of the population speaks. We then calculated the share of each type of democratic government system for each linguistic group and year. Similarly, we referred to data from World Religion Data (WRD; Maoz and Henderson 2013) to identify countries with a dominant religion (with $60 \%$ or more of the population as a dominance threshold) and create a variable that identifies groups of countries with the same dominant religion. We then used that variable to calculate the share of each type of democratic government system for each religious group and year. We also calculated the share of each type of democratic government system for each post-colonial group-consisting of countries governed by the same colonial power prior to independence-and year. We reviewed information from the Quality of Government (QoG) dataset to identify colonial backgrounds and form groups of countries.

Third, to measure system density in post-autocratic networks, we used information from Democracy and Dictatorship to identify pre-democratisation autocratic regime types. The database provides three categories of autocratic regimes: military dictatorship, civil dictatorship and monarchy. The ruling elite in military dictatorships is, of course, the military (junta). A civil dictatorship is led by a regime party that constitutes the ruling elite. Monarchies are led by ruling elites reliant on a familial and kin network (Cheibub et al. 2010). To measure democratic government system density in these networks, we created a variable indicating the share of each democratic government system in countries that transitioned from the same autocratic regime type the year prior to democratisation.

Although we include a variety of networks that studies on democratic diffusion have previously examined, the set of networks is not complete. Our analysis, for example, does not consider diffusion within economic networks or international organisations. When democratisation occurs at the time of independence, there is naturally a lack of information concerning the country's economic and diplomatic relations in the preceding year. As a result, data is missing for more than $30 \%$ of the cases and those two network types had to be excluded. Additionally, as the hypothesis concerns how democratic systems of government in countries affect system choice in other countries, the design of this analysis indicates interdependence, which refers 
to a correlation between spatial units rather than the spatial-temporal processes that spreads democratic systems (Darmofal 2015; Ward and Gleditsch 2008).

\subsection{Control variables}

We included control variables to ensure that correlation between diffusion variables and the establishment of a particular system is not spurious. However, the low number of observations restricts our ability to include variables. Therefore, we have selected variables that, according to previous studies, are significant to the establishment of democratic government systems.

The first control variable is socio-economic modernisation index consisting of four indicators: logarithm of real GDP per capita (PPP converted to 2000 prices), life expectancy at birth (in years), average educational attainment (average number of years among citizens 16 and older) and urbanisation (urban proportion of the total population). As Table 1 shows, these four indicators are strongly correlated with a latent factor. To avoid multicollinearity issues, we used factor analysis scores as an index of socio-economic modernisation. Numerous studies have argued that the outcomes of political processes are more uncertain in countries with low levels of socio-economic modernisation; they tend to choose parliamentary over presidential regimes to promote stability (Frye 1997; Geddes 1996; Jung and Deering 2015). This socio-economic control variable is thus expected to have a positive effect on the probability of presidential and semi-presidential regimes and a negative effect on the probability of a parliamentary regime.

The second control variable indicates population size. Mainwaring and Shugart (1997) showed a correlation between size and governmental form. Small countries tend to establish parliamentary democracies while medium and large countries tend to opt for presidential democracy. The theoretical explanation is that small states tend to be more culturally, ethnically and socially homogeneous than larger ones; this homogeneity promotes political stability and reduces the need for a strong system of checks and balances. While Jung and Deering (2015) did not find empirical support for the significance of population size, we included a logarithmic variable to control for any potential effects of population size on the choice of a democratic system of government.

Our third control variable, regime heritage, indicates whether the country has previously had the same democratic system of government as the one established at the time of democratisation. An alternative mode of diffusion to the spatial variety is temporal diffusion, which refers to processes that spread the experience of democratic institutions over time within the same country and affect the contemporary decisions of democratic institutions (Capoccia and Ziblatt 2010; Møller 2013). For example, Geddes (1996) found that countries in Latin America tend to re-establish presidential regimes after periods of autocracy. This variable aims to control for the effects of temporal diffusion on institutional choices; it is a dummy variable that codes countries that have previously had the same democratic system of government as 1 and countries that established a particular democratic system of government for the first time as value 0 . This variable is used to determine whether countries tend to re-establish the same democratic system that they had during a previous period. 
Table 1 Factor analysis of socio-economic modernization

\begin{tabular}{lll}
\hline Variable & Factor loading & Extraction \\
\hline Real GDP per capita & 0.903 & 0.815 \\
Life expectancy & 0.898 & 0.807 \\
Education level & 0.938 & 0.880 \\
Urbanization & 0.884 & 0.782 \\
Eigenvalue & 3.283 & - \\
Explained variance & 82.077 & - \\
KMO & 0.842 & - \\
Bartlett's test of Sphericity & 381.718 & - \\
(significance) & $(0.000)$ & \\
\hline
\end{tabular}

The fourth control variable indicates the number of past transitions from an autocratic to a democratic regime; it is used as a proxy for political instability. One major aspect of democratic government systems is their ability to counteract political instability. Linz $(1990,1994)$ argued that presidential regimes have a weaker ability to promote political stability because the separation of executive and legislative powers creates deadlock between political actors, institutional inefficacy in decision-making, and the potential for regime breakdown. Some studies have found empirical support for this claim (Mainwaring 1993) while others have criticised the supposed correlation (Cheibub 2007; Power and Gasiorowski 1997). However, these studies looked at the correlation between democratic government system and regime breakdown. Our analysis aims to test whether historical experience with political instability affects the choice of democratic systems of government. We expect, in line with Linz (1990, 1994) and Mainwaring (1993), that countries with a history of political instability would choose a democratic system that promotes stability (a parliamentary regime) over one that increases the probability of instability (a presidential or semipresidential regime).

The fifth control variable indicates whether the democratic regime was established in the context of state formation. Previous studies have found that democratisation in new states runs a higher risk of failure than that in consolidated states (Denk and Lehtinen 2019; Linz and Stepan 1996; Rost and Booth 2008). Democratisation in a new state faces the twin challenges of creating a new state and establishing a democratic regime. In this situation, actors must choose a democratic system of government within a context of high political uncertainty, meaning they tend to choose that which promotes political stability - a parliamentary regime (Jung and Deering 2015). Hence, we expect the probability of parliamentary democracy to be higher in new states than in consolidated states and presidential and semipresidential regimes to be more common in consolidated states. We used a variable with the value of 1 for cases of democratisation in new states and the value of 0 for cases of democratisation in consolidated states.

The final control variable concerns colonial heritage and focuses on the relationship between former colonies and their respective former powers. Studies have argued that colonial heritage influences their choice of democratic regime, but through processes other than diffusion (Amorim Neto and Costa Lobo 2014; Jung and Deering 2015; Persson and Tabellini 2003). We found a similar pattern. Former British 
Table 2 Measurement of variables

\begin{tabular}{|c|c|c|}
\hline Variable & $\begin{array}{l}\text { Measurement } \\
\text { (Data source) }\end{array}$ & Scale information \\
\hline $\begin{array}{l}\text { Democratic regime } \\
\text { type }\end{array}$ & $\begin{array}{l}\text { Binary variables } \\
\text { (DD) }\end{array}$ & $\begin{array}{l}0=\text { other democratic regime types } \\
1=\text { the specific regime type }\end{array}$ \\
\hline Global diffusion & $\begin{array}{l}\text { Aggregated variable } \\
\text { (DD) }\end{array}$ & $0-100$ \\
\hline Continental diffusion & $\begin{array}{l}\text { Aggregated variable } \\
\text { (DD) }\end{array}$ & $0-100$ \\
\hline Regional diffusion & $\begin{array}{l}\text { Aggregated variable } \\
\text { (DD) }\end{array}$ & $0-100$ \\
\hline $\begin{array}{l}\text { Neighbourhood diffu- } \\
\text { sion }\end{array}$ & $\begin{array}{l}\text { Aggregated variable } \\
\text { (DD/Direct Contiguity) }\end{array}$ & $0-100$ \\
\hline $\begin{array}{l}\text { Linguistic network } \\
\text { diffusion }\end{array}$ & $\begin{array}{l}\text { Aggregated variable } \\
\text { (DD/Melitz (2008)/CIA) }\end{array}$ & $0-100$ \\
\hline $\begin{array}{l}\text { Religion network } \\
\text { diffusion }\end{array}$ & $\begin{array}{l}\text { Aggregated variable } \\
\text { (DD/WRD) }\end{array}$ & $0-100$ \\
\hline $\begin{array}{l}\text { Postcolonial network } \\
\text { diffusion }\end{array}$ & $\begin{array}{l}\text { Aggregated variable } \\
(\mathrm{DD} / \mathrm{COW})\end{array}$ & $0-100$ \\
\hline $\begin{array}{l}\text { Post-autocratic net- } \\
\text { work diffusion }\end{array}$ & $\begin{array}{l}\text { Aggregated variable } \\
\text { (DD) }\end{array}$ & $0-100$ \\
\hline $\begin{array}{l}\text { Socio-economic mod- } \\
\text { ernization }\end{array}$ & $\begin{array}{l}\text { Index variable } \\
\text { (NMC/QoG/V-DEM) }\end{array}$ & - \\
\hline Population & $\begin{array}{l}\text { Logarithmic variable } \\
\text { (NMC/QoG/DEM) }\end{array}$ & From 0 \\
\hline Regime heritage & $\begin{array}{l}\text { Binary variable } \\
\text { (DD) }\end{array}$ & $\begin{array}{l}0=\text { no } \\
1=\text { yes }\end{array}$ \\
\hline $\begin{array}{l}\text { Number of past transi- } \\
\text { tions }\end{array}$ & $\begin{array}{l}\text { Cumulative variable } \\
\text { (DD) }\end{array}$ & $0-4$ \\
\hline $\begin{array}{l}\text { Mode of democratiza- } \\
\text { tion }\end{array}$ & $\begin{array}{l}\text { Binary variable } \\
\text { (DD) }\end{array}$ & $\begin{array}{l}0=\text { democratic transition } \\
1=\text { state formation }\end{array}$ \\
\hline Colonial heritage & $\begin{array}{l}\text { Binary variable } \\
\text { (DD/COW) }\end{array}$ & $\begin{array}{l}0=\text { no colonial heritage of regime type } \\
1=\text { colonial heritage of regime type }\end{array}$ \\
\hline
\end{tabular}

colonies tended to choose parliamentary regimes while former French and Portuguese colonies have favoured semi-presidential regimes and former Spanish and Dutch colonies have generally established presidential regimes. The assumed explanation is that former colonies often imitate their colonial institutions or that the colonial powers have influenced the choices of their former colonies. Thus, we included a variable indicating colonial heritage. If countries have a colonial background we expect to favour the adoption of a particular democratic system, we coded their cases as 1 ; if not, they are coded as 0 . In contrast to the post-colonial network variable, which concerns system choice in countries with the same former colonial power, this variable refers to the historical relationship between the former colonial power and the country.

Table 2 summarises the variables included in our analysis. As the three dependent variables (the democratic government system) have a binary structure, we used logis- 
tic regression to analyse the material in multivariate analyses. ${ }^{3}$ To reduce problems with reversed causality and causal lags, we lagged the independent variables by one year (t-1) with the exception of domestic variable values for cases of democratisation by state formation, as statistics on domestic conditions begin the year a state becomes independent. The use of a temporal structure with one-year lagged variables is conventional in studies on democratic diffusion. It ensures that the independent variables are measured prior to democratisation and the establishment of democratic government system. Furthermore, the research assumes that temporally proximate situations have relatively strong effects. We also assumed that the choice of democratic system did not influence the conditions at the time of independence because systems need more time to have such influence. To measure the variables, as reported in Table 2, we consulted databases frequently used in research on political regimes: Democracy and Dictatorship (DD; Alvarez et al. 1996; Cheibub et al. 2010), Direct Contiguity (Stinnett et al. 2002), the Correlates of War Project (COW), National Material Capabilities (NMC; Singer 1987), Quality of Government (QOG; Teorell et al. 2016), Varieties of Democracy (V-Dem; Coppedge et al. 2015) and World Religion Data (Maoz and Henderson 2013). These databases use transparent coding criteria to develop reliable indicators that provide comparable information from countries and periods. To ensure validity and enable comparison with previous studies, we utilized conventional and internationally recognized databases.

\section{Empirical results}

As Table 3 illustrates, democratic systems of government vary in different contexts. Parliamentary and presidential regimes have dominated among the cases. The shares of these two types are almost equal, while there have been few semi-presidential regimes established. ${ }^{4}$ However, there are differences between democratisation through democratic transition and democratisation through state formation. A majority of countries following democratic transition established presidential regimes; a majority of countries following state formation established parliamentary regimes. The prevalence of semi-presidential regimes is equally as common in both cases. Furthermore, Table 3 shows how the chosen democratic system of government is temporally and spatially clustered in some respects. According to correlation analysis, which presents the connection with lambda coefficients $(\lambda)$, there are significant differences between periods concerning the establishment of the democratic government systems. In three periods (1946-1949, 1960-1969 and 1970-1979) a majority of cases established parliamentary regimes, while the establishment of presidential regimes dominated (50\% or more) in two periods (1950-1959 and 1980-1989).

\footnotetext{
3 An alternative to this design would be a multinomial regression design. However, the hypothesis requires diffusion variables that specify the share of each type of democratic system within networks. Therefore, the independent variables are not the same in the analysis of the three system types (as they would be in a multinominal regression model).

${ }^{4}$ Categorisations of semi-presidential regimes have long been debated. However, $91 \%$ of semi-presidential regime cases in our analysis overlap with the categorisation from a semi-presidentialism database and have not affected our result to any serious degree (Elgie 2018).
} 
Table 3 Democratic regime types after democratisation

\begin{tabular}{|c|c|c|c|c|c|}
\hline & \multicolumn{2}{|c|}{ The mode of democratic regimes } & \multirow[b]{2}{*}{$\begin{array}{l}\text { Presidential } \\
\text { regime }\end{array}$} & \multirow[b]{2}{*}{$\begin{array}{l}\text { Lambda } \\
\text { (significance) }\end{array}$} & \multirow[b]{2}{*}{ Cases } \\
\hline & $\begin{array}{l}\text { Parliamentary } \\
\text { regime }\end{array}$ & $\begin{array}{l}\text { Semi-presi- } \\
\text { dential } \\
\text { regime }\end{array}$ & & & \\
\hline Total & 43.3 & 16.3 & 40.3 & - & 141 \\
\hline \multicolumn{6}{|c|}{ Mode of democratization } \\
\hline $\begin{array}{l}\text { Democratic } \\
\text { transition }\end{array}$ & 29.8 & 5.3 & 64.9 & \multirow[t]{2}{*}{$\begin{array}{l}0.250 \\
(0.005)\end{array}$} & 57 \\
\hline State formation & 52.4 & 23.8 & 23.8 & & 84 \\
\hline \multicolumn{6}{|l|}{ Period } \\
\hline 1946-1949 & 64.3 & 0.0 & 35.7 & \multirow{2}{*}{$\begin{array}{l}0.213 \\
(0.004)\end{array}$} & 14 \\
\hline $1950-1959$ & 30.0 & 0.0 & 70.0 & & 10 \\
\hline 1960-1969 & 72.2 & 0.0 & 27.8 & - & 18 \\
\hline 1970-1979 & 57.1 & 14.3 & 28.6 & - & 21 \\
\hline 1980-1989 & 29.6 & 7.4 & 63.0 & - & 27 \\
\hline 1990-1999 & 32.4 & 38.2 & 29.4 & - & 34 \\
\hline 2000-2008 & 29.4 & 29.4 & 41.2 & - & 17 \\
\hline \multicolumn{6}{|l|}{ Continent } \\
\hline Africa & 27.8 & 33.3 & 38.9 & \multirow{2}{*}{$\begin{array}{l}0.350 \\
(0.001)\end{array}$} & 36 \\
\hline Americans & 25.0 & 0.0 & 75.0 & & 48 \\
\hline Asia & 66.7 & 13.9 & 19.4 & - & 36 \\
\hline Europe & 68.4 & 31.6 & 0.0 & - & 19 \\
\hline Oceania & 100.0 & 0.0 & 0.0 & - & 2 \\
\hline \multicolumn{6}{|l|}{ Region } \\
\hline Caribbean & 90.9 & 0.0 & 9.1 & \multirow{2}{*}{$\begin{array}{l}0.563 \\
(0.000)\end{array}$} & 11 \\
\hline Central America & 7.7 & 0.0 & 92.3 & & 13 \\
\hline Eastern Africa & 12.5 & 25.0 & 62.5 & - & 8 \\
\hline Eastern Asia & 66.7 & 0.0 & 33.3 & - & 3 \\
\hline Eastern Europe & 50.0 & 50.0 & 0.0 & - & 6 \\
\hline Melanesia & 100.0 & 0.0 & 0.0 & - & 2 \\
\hline Middle Africa & 0.0 & 75.0 & 25.0 & - & 4 \\
\hline Northern Africa & 100.0 & 0.0 & 0.0 & - & 6 \\
\hline Northern Europe & 66.7 & 3.3 & 0.0 & - & 3 \\
\hline South America & 4.2 & 0.0 & 95.8 & - & 24 \\
\hline $\begin{array}{l}\text { South-Eastern } \\
\text { Asia }\end{array}$ & 77.8 & 0.0 & 22.2 & - & 9 \\
\hline Southern Asia & 66.8 & 18.8 & 12.5 & - & 16 \\
\hline Southern Europe & 75.0 & 25.0 & 0.0 & - & 8 \\
\hline Western Africa & 16.7 & 38.9 & 44.4 & - & 18 \\
\hline Western Asia & 50.0 & 25.0 & 25.0 & - & 8 \\
\hline Western Europe & 100.0 & 0.0 & 0.0 & - & 2 \\
\hline
\end{tabular}


Semi-presidential regimes have never dominated in any period, though they were most prominent in the latest two periods (1990-1999 and 2000-2008). As semipresidential regimes became more prominent in these periods, the general patterns became more fragmented.

The correlation coefficients indicate that the spatial clustering is even stronger at the continental level. Parliamentary regimes dominate among the cases in Oceania, Europe and Asia while a majority of the cases in the Americas resulted in presidential regimes. We found the highest share of semi-presidential regimes among African and European cases, though they never constituted a majority. However, semi-presidential regimes have been more prominent in some regions within continents. The only case in Central Asia and a majority of cases in Middle Africa resulted in semipresidential regimes; there were also high shares in Eastern Europe, Southern Europe and Western Africa. There are also other variations among regions within the same continent. For instance, nearly all cases in the Caribbean resulted in parliamentary regimes while presidential regimes dominate in other American regions. With the exception of Eastern Europe, Southern Europe, and Western Africa, one particular system of government dominates within each region. In sum, there is temporal and spatial clustering of democratic systems. Other studies have found similar patterns (e.g., Jung and Deering 2015) even if they have not focused on the establishment of democratic regimes at the time of independence. These results do not, however, provide sufficient evidence to conclude that system choice is the result of diffusion between countries. They indicate spatial autocorrelation, which may be caused by diffusion, but this could also stem from the clustering of endogenous conditions for political regimes (Darmofal 2015; Ward and Gleditsch 2008). Therefore, in the next step, we determine whether diffusion caused the spatial correlations associated with the choice of a democratic government system at the time of democratisation.

One method to analyse the effects of diffusion that other studies have used is to include network government-system density, as measured by the share of countries with a democratic system type among the countries, as an independent variable (e.g., Brinks and Coppedge 2006; Darmofal 2015; Gleditsch and Ward 2006; Jung and Deering 2015; Starr and Lindborg 2003; Teorell 2010; Wong and Woodberry 2015). This approach is problematic, however, when analysis uses several indicators of network system density. State network memberships overlap, meaning there is dependence between the networks. Thus, there are reasons to expect correlation between network government-system densities and subsequent multicollinearity problems if the correlations are strong; if there is high multicollinearity it means that the indicators of regime density measure the same variation. This would result in an increase in the error margins of coefficients and a higher probability of rejecting a true hypothesis (i.e., a type II-error). It would also lead to unstable situations in which minor changes to the data lead to significant changes in the coefficients and an overestimation of the goodness-of-fit of the model (Allison 1999; Lewis-Beck 1993).

To test the correlation between network regime-density indicators, we conducted factor analysis, of which Table 4 presents the outcomes-there are strong correlations. First, for parliamentary regimes, the analysis identifies three latent factors: regime density in continental, regional, neighbourhood and post-colonial networks 


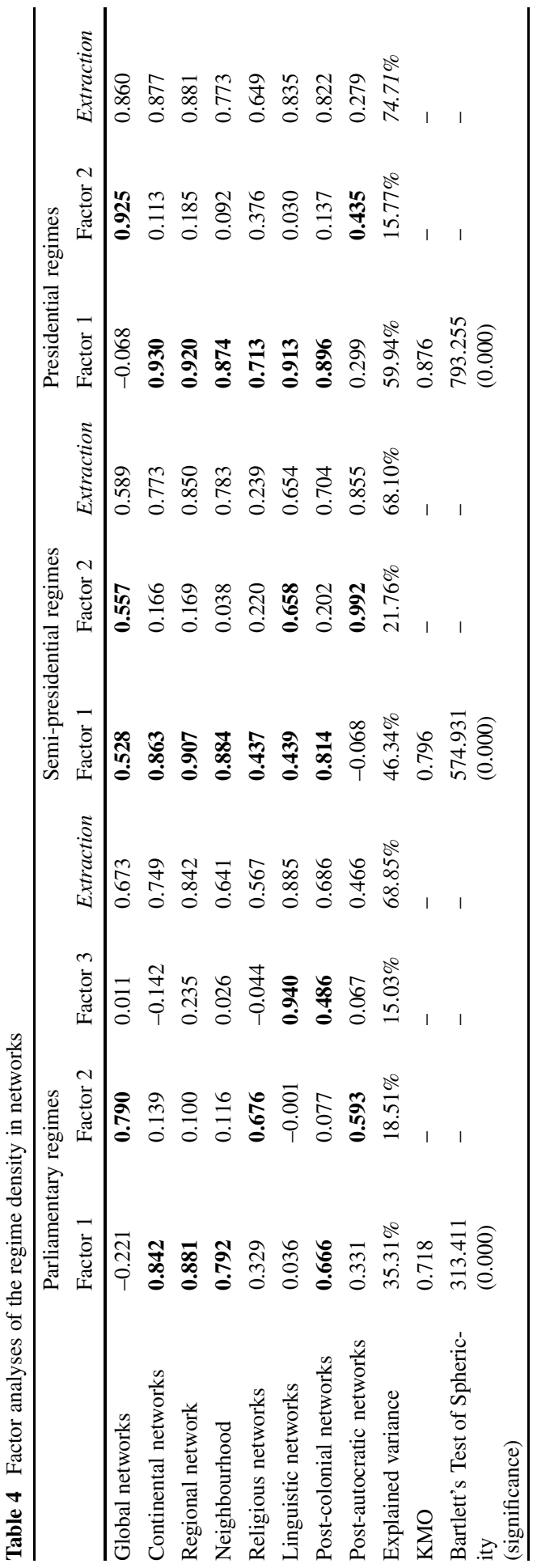


(a combination of geographical and political networks); global, religious and postautocratic networks (geographical, cultural and political networks), and; cultural and political networks (linguistic and post-colonial networks). Second, the density of semi-presidential regimes in networks constitutes two factors. All indicators except post-autocratic networks are part of the first factor, indicating that the variations in most networks are highly correlated. As Table 3 shows, the introduction of semipresidential regimes is concentrated temporally and spatially in a few regions in the 1990s; the countries in these regions have similarities in religion, language and postcolonial heritage. The second factor includes global networks, linguistic networks and post-autocratic networks. Geographical, cultural and political networks are thus represented in both factors. Third, the introduction of presidential regimes is also concentrated in time and space but occurs in more waves than that of semi-presidential regimes. This pattern results in two factors. For one, there are strong correlations between geographical, religious, linguistic and post-colonial networks. The second factor is comprised of two indicators: global networks and post-autocratic networks. To measure network-regime densities, we used factor analysis scores to create three indexes for parliamentary regimes, two indexes for semi-presidential regimes and two indexes for presidential regimes. These factors measure system density in networks that countries were members of one year prior to state formation or democratic transition.

Table 5 presents the results from our logistic regression analyses, which include indexes that measured the density of regime types in networks together with the control variables (Models 1, 3 and 5). These results indicate that there are diffusion effects on all democratic regime types. The share of parliamentary democracies in geopolitical networks (Index I) increases the probability that a country in the network chooses a parliamentary regime at the time of democratisation. To a lesser but significant degree, the probability also increases as the share of parliamentary democracy increases in linguistic and post-colonial networks (Index III); in contrast, the share in religious and post-authoritarian networks does not affect the probability (Index II). The composition of geographical, cultural and post-colonial networks also influences the probability of semi-presidential regime establishment at the time of democratisation (Index I). The odds quota for the first index indicates that the probability of semi-presidential regime establishment increases alongside the share of semi-presidential regimes in these networks. However, the effect of the second index is not significant, meaning that the share in global, linguistic and post-authoritarian networks does not affect the likelihood for the introduction of a semipresidential regime at the time of democratisation (Index II). The result is similar for presidential regimes. The share of presidential regimes in geographical, cultural and post-colonial networks (Index I) affects the probability that a country decides to establish a presidential regime at the time of democratisation, while the composition of global and post-authoritarian networks (Index II) does not change the probability. In sum, the results indicate that regime diffusion affects the choice of democratic system type at the time of democratisation. At least one index has significant effects on the probability to establish a democratic system type. However, the results also show that the significance of the networks diverges. Five networks are part of all indexes with significant effects: continental, regional, neighbourhood, linguistic and 
Table 5 Logistic regression analyses

\begin{tabular}{|c|c|c|c|c|c|c|}
\hline & \multicolumn{2}{|c|}{$\begin{array}{l}\text { Parliamentary } \\
\text { democracy }\end{array}$} & \multicolumn{2}{|c|}{$\begin{array}{l}\text { Semi-presidential } \\
\text { democracy }\end{array}$} & \multicolumn{2}{|c|}{$\begin{array}{l}\text { Presidential } \\
\text { democracy }\end{array}$} \\
\hline & Model 1 & Model 2 & Model 3 & Model 4 & Model 5 & Model 6 \\
\hline $\begin{array}{l}\text { Parliamentary density } \\
\text { index I }\end{array}$ & $\begin{array}{l}21.392 \\
(0.000)\end{array}$ & - & - & - & - & - \\
\hline $\begin{array}{l}\text { Parliamentary density } \\
\text { index II }\end{array}$ & $\begin{array}{l}1.245 \\
(0.548)\end{array}$ & - & - & - & - & - \\
\hline $\begin{array}{l}\text { Parliamentary density } \\
\text { index III }\end{array}$ & $\begin{array}{l}3.787 \\
(0.006)\end{array}$ & - & - & - & - & - \\
\hline $\begin{array}{l}\text { Semi-presidential } \\
\text { density index I }\end{array}$ & - & - & $\begin{array}{l}3.752 \\
(0.001)\end{array}$ & - & - & - \\
\hline $\begin{array}{l}\text { Semi-presidential } \\
\text { density index II }\end{array}$ & - & - & $\begin{array}{l}1.690 \\
(0.151)\end{array}$ & - & - & - \\
\hline $\begin{array}{l}\text { Presidential density } \\
\text { index I }\end{array}$ & - & - & - & - & $\begin{array}{l}210.457 \\
(0.000)\end{array}$ & - \\
\hline $\begin{array}{l}\text { Presidential density } \\
\text { index II }\end{array}$ & - & - & - & - & $\begin{array}{l}1.488 \\
(0.348)\end{array}$ & - \\
\hline $\begin{array}{l}\text { Socio-economic mod- } \\
\text { ernization (index) }\end{array}$ & $\begin{array}{l}0.325 \\
(0.016)\end{array}$ & $\begin{array}{l}1.124 \\
(0.632)\end{array}$ & $\begin{array}{l}0.735 \\
(0.496)\end{array}$ & $\begin{array}{l}1.716 \\
(0.094)\end{array}$ & $\begin{array}{l}0.451 \\
(0.086)\end{array}$ & $\begin{array}{l}0.836 \\
(0.573)\end{array}$ \\
\hline Population (log) & $\begin{array}{l}0.862 \\
(0.799)\end{array}$ & $\begin{array}{l}1.453 \\
(0.259)\end{array}$ & $\begin{array}{l}1.329 \\
(0.600)\end{array}$ & $\begin{array}{l}1.403 \\
(0.421)\end{array}$ & $\begin{array}{l}0.928 \\
(0.911)\end{array}$ & $\begin{array}{l}1.370 \\
(0.459)\end{array}$ \\
\hline Regime heritage & $\begin{array}{l}0.169 \\
(0.142)\end{array}$ & $\begin{array}{l}0.066 \\
(0.015)\end{array}$ & $\begin{array}{l}0.144 \\
(0.118)\end{array}$ & $\begin{array}{l}0.320 \\
(0.290)\end{array}$ & $\begin{array}{l}2.306 \\
(0.443)\end{array}$ & $\begin{array}{l}7.637 \\
(\mathbf{0 . 0 1 3 )}\end{array}$ \\
\hline $\begin{array}{l}\text { Number of demo- } \\
\text { cratic transitions }\end{array}$ & $\begin{array}{l}2.639 \\
(0.018)\end{array}$ & $\begin{array}{l}0.822 \\
(0.420)\end{array}$ & $\begin{array}{l}0.610 \\
(0.340)\end{array}$ & $\begin{array}{l}0.810 \\
(0.569)\end{array}$ & $\begin{array}{l}1.061 \\
(0.898)\end{array}$ & $\begin{array}{l}1.119 \\
(0.720)\end{array}$ \\
\hline $\begin{array}{l}\text { Mode of democratisa- } \\
\text { tion }\end{array}$ & $\begin{array}{l}2.311 \\
(0.353)\end{array}$ & $\begin{array}{l}1.168 \\
(0.788)\end{array}$ & $\begin{array}{l}0.775 \\
(0.637)\end{array}$ & $\begin{array}{l}3.327 \\
(0.124)\end{array}$ & $\begin{array}{l}0.078 \\
(0.068)\end{array}$ & $\begin{array}{l}0.917 \\
(0.907)\end{array}$ \\
\hline Colonial heritage & $\begin{array}{l}0.939 \\
(0.946)\end{array}$ & $\begin{array}{l}3.447 \\
(0.042)\end{array}$ & $\begin{array}{l}14.163 \\
(0.004)\end{array}$ & $\begin{array}{l}31.608 \\
(0.000)\end{array}$ & $\begin{array}{l}0.132 \\
(0.089)\end{array}$ & $\begin{array}{l}98.137 \\
(0.000)\end{array}$ \\
\hline Constant & $\begin{array}{l}0.107 \\
(0.328)\end{array}$ & $\begin{array}{l}0.148 \\
(0.172)\end{array}$ & $\begin{array}{l}0.065 \\
(0.252)\end{array}$ & $\begin{array}{l}0.020 \\
(0.051)\end{array}$ & $\begin{array}{l}9.618 \\
(0.412)\end{array}$ & $\begin{array}{l}0.058 \\
(0.139)\end{array}$ \\
\hline Nagelkerke's $R^{2}$ & 0.699 & 0.276 & 0.590 & 0.452 & 0.814 & 0.629 \\
\hline Number of cases & 121 & 121 & 121 & 121 & 121 & 121 \\
\hline \multicolumn{7}{|c|}{ Correct predicted cases (\%) } \\
\hline All cases & 86.0 & 71.1 & 94.8 & 84.3 & 93.4 & 85.1 \\
\hline $\begin{array}{l}\text { The specific regime } \\
\text { type }\end{array}$ & 78.0 & 39.0 & 58.3 & 45.8 & 89.3 & 75.0 \\
\hline Other regime types & 90.0 & 87.5 & 87.6 & 93.8 & 96.9 & 93.8 \\
\hline
\end{tabular}

The table presents coefficients of logistic regression $(\operatorname{Exp}(B))$ and the level of significance in parentheses

post-colonial. When global networks and religious networks correlate with these networks and are included in the same indexes as them, the regime density in them becomes relevant. Post-autocratic networks are not part of any index with significant effects.

One alternative way to illustrate the significance of diffusion networks is to compare models with diffusion variables with those that only include the control variables. Therefore, Table 4 includes three models (Models 2, 4 and 6) with just the control variables. A general pattern emerges when we compare the two sets of mod- 
els. The coefficient for the goodness-of-fit (Nagelkerke's $\mathrm{R}^{2}$ ) shows a considerable increase when the models contain the diffusion indexes compared to the models with control variables only. The increase is present for all regime types, though it is highest for parliamentary regimes where the coefficient increases from 27.6 to $69.9 \%$. However, the coefficients for the semi-presidential regime type and the presidential regime type also increase when the diffusion variables become part of the analysis. While the increase in these two regimes is smaller, the changes are still substantial, from 45.2 to $59.0 \%$ (semi-presidential regime type) and from 62.9 to $81.4 \%$ (presidential regime type). Furthermore, the share of correctly predicted cases followed the same pattern and increased when the analysis included diffusion variables, indicating that the models with diffusion variables more effectively predict the selection of a democratic regime type. This share increased for all systems though it did so by the most for parliamentary systems (39.0 to 78.0\%). However, the share of correctly predicted cases with semi-presidential or presidential systems also increased (45.8 to $58.3 \%$ and from 75.0 to $89.3 \%$ ). Moreover, the results indicate that the heteroscedasticity is lower when the model includes diffusion variables. The models without diffusion variables offer a better explanation of why actors have not established in a specific democratic regime type than why actors have established the democratic regime type at the time of democratisation.

According to our empirical analysis, it is not only regime diffusion that affects democratic system choice. As shown in Table 5, some of the control variables have significant effects on the probability of the establishment of a particular regime type. For instance, socio-economic modernisation has negative effects on the probability of a parliamentary system being established. These results suggest that parliamentary regimes have been established in less-developed countries and that the choice of parliamentary regimes is, at least in this sense, tied to domestic conditions. Parliamentary regimes are also more common for democratisation at the time of independence than after democratic transitions. Colonial heritage (the former colonial ruler of a former colony) increases the probability of actors establishing a semipresidential regime at the time of democratisation, even when the index of diffusion is included. They are more common among former French and Portuguese colonies than among others. However, according to the analysis (Model 5), there are no similar effects on the establishment of presidential regimes. Instead, only the first diffusion index has a significant effect on the establishment of presidential regimes. Of the three democratic government types, the presidential regime is the most strongly related to diffusion within international networks.

The results support the idea that diffusion affects government system choice at the time of democratisation. All models included one or two diffusion indexes that significantly affect regime choice. The effects were high, and the coefficients of Nagelkerke's $\mathrm{R}^{2}$ indicated a high degree of goodness-of-fit, which increased as diffusion indexes were included. Results indicate that the choice between parliamentary, presidential and semi-presidential regimes is influenced by geographical, cultural, and post-colonial networks. However, as our factor analysis illuminates, network structures are complex due to correlation between network system densities. Therefore, we accept the hypothesis on the diffusion of democratic government systems with some reservation. This type of diffusion appears to affect government 
system choice at the time of democratisation but it does so in overlapping networks and not in all networks.

\section{Conclusions and discussion}

Starting from the observation that countries have established different forms of democratic government at the time of democratisation, this article sought to explore whether diffusion explains this variation. While previous studies have largely focused on domestic determinants, we found empirical indicators of diffusion effects within country networks. The empirical results support the hypothesis that choice of democratic system type at the time of democratisation is affected by diffusion. A higher density of a particular democratic system in country networks increases the probability of the establishment of that system at the time of democratisation in other countries within the same network. This conclusion provides an explanation for variation in democratic government system choice. When political elites make decisions about government systems, they do not do so in a vacuum, influenced only by domestic considerations. They are also influenced by government systems in countries within their networks. Government systems in other countries and the experiences with those systems seem to serve as reference points for political elites' decision-making.

With this finding, the study contributes to research on both democratic diffusion and democratic government systems. Studies on the diffusion of democratic regimes have already shown that diffusion affects the likelihood of democratic transition (e.g., Brinks and Coppedge 2006; Gassebner et al. 2013; Gleditsch and Ward 2006; Starr and Lindborg 2003; Teorell 2010; Wejnert 2005, 2014). The contribution of this study to the literature on democratic diffusion is that diffusion influences not only the establishment of democratic institutions on a general level but also the establishment of particular forms of democratic government. By highlighting the impact of diffusion on the choice of government type, this study also contributes to the literature on institutional adoption amid democratisation. Previous studies have assumed that institutional choices are primarily the outcome of elite bargaining aimed at handling uncertainty and ensuring power for themselves in the new order (e.g., Frye 1997; Jung and Deering 2015; Mainwaring and Shugart 1997; Persson and Tabellini 2003). These studies have therefore focused almost entirely on domestic conditions. Our results indicate, however, that institutional choice is not only affected by domestic factors-decision-makers consider external conditions and use them as reference points. Given this fact, and to avoid problems with endogeneity, future studies on institutional choice should include external conditions in general, and diffusion in particular. They should also explore whether other external or internal conditions explain the establishment of democratic government system, but also test other relationships between the conditions offered by the logistic regression model.

While the results contribute to major discussions on democratic diffusion and democratic government systems, they also raise questions that must be answered by future studies. One area that should be examined further is under which conditions networks affect the establishment of government system at the time of democratisa- 
tion. According to our analysis, the effects of diffusion are stronger for parliamentary systems than for semi-presidential and presidential systems. The analysis shows differences in network influences as well as diverse contextual conditions for diffusion, such as modernisation, historical legacy and international institutions (Wejnert 2014). As shown in Table 2, different geographical areas, periods and processes (such as state formation or democratic transition) can influence system choice. The precise impact of these contextual differences on democratic diffusion has yet to be explored. Furthermore, as our model for semi-presidential regimes shows the lowest goodness-of-fit, the explanation of semi-presidential establishment calls for analysis including a wider set of independent variables or considering institutional differences between semi-presidential regimes. These variables may be found in the domestic context of semi-presidential countries or in the particular nature of their transitional processes. The mechanisms of democratic government system diffusion also require further review. This analysis, like most diffusion studies, identified strong correlations between democratic institutions within networks. However, how these systems are transmitted and evolve in networks has yet to be explored. Future studies must unpack these causal mechanisms and determine whether the same processes spread general democratisation and particular democratic systems. Finally, future studies could determine whether diffusion occurs when a government system is established at a time other than democratisation; this would allow for the consideration of factors outside the context of democratisation.

Funding This article was sponsored by the Swedish Research Council, grant number VR2014-1260, and by the Intercultural Studies at Dalarna University. We wish to thank the colleagues at the higher seminar Transition, Identity, and Civil Society at Dalarna University for their valuable feedback on earlier drafts of the article. The authors also wish to thank two anonymous reviewers at Zeitschrift für Vergleichende Politikwissenschaft for their insightful and constructive comments that have improved the article in several aspects.

Funding Open access funding provided by Dalarna University.

Open Access This article is licensed under a Creative Commons Attribution 4.0 International License, which permits use, sharing, adaptation, distribution and reproduction in any medium or format, as long as you give appropriate credit to the original author(s) and the source, provide a link to the Creative Commons licence, and indicate if changes were made. The images or other third party material in this article are included in the article's Creative Commons licence, unless indicated otherwise in a credit line to the material. If material is not included in the article's Creative Commons licence and your intended use is not permitted by statutory regulation or exceeds the permitted use, you will need to obtain permission directly from the copyright holder. To view a copy of this licence, visit http://creativecommons.org/licenses/by/4. $0 /$.

Conflict of interest J. Åberg and T. Denk declare that they have no competing interests.

\section{References}

Allison, Paul B. 1999. Multiple regression. London.: SAGE.

Alvarez, Mike, José Antonio Cheibub, Fernando Limongi, and Adam Przeworski. 1996. Classifying political regimes. Studies in Comparative International Development 31(2):3-36.

Amorim Neto, Octavio, and Marina Costa Lobo. 2014. Semi-presidentialism in lusophone countries: diffusion and operation. Democratization 21(3):434-457. 
Beck, Nathaniel, Kristian Skrede Gleditsch, and Kyle Beardsley. 2006. Space is more than geography: using spatial econometrics in the study of political economy. International Studies Quarterly 50(1):27-44.

Bernhard, Michael, Christopher Reenock, and Timothy Nordstrom. 2004. The legacy of western overseas colonialism on democratic survival. International Studies Quarterly 48(1):225-250.

Braun, Dietmar, and Fabrizio Gilardi. 2006. Taking 'Galton's problem' seriously: towards a theory of policy diffusion. Journal of Theoretical Politics 18(3):298-322.

Brinks, Daniel, and Michael Coppedge. 2006. Diffusion is no illusion: neighbor emulation in the third wave of democracy. Comparative Political Studies 39(4):463-489.

Bunce, Valerie J., and Sharon L. Wolchik. 2000. International diffusion and postcommunist electoral revolutions. Communist and Post-Communist Studies 39(3):283-304.

Capoccia, Giovanni, and Daniel Ziblatt. 2010. The historical turn in democratization studies: a new research agenda for Europe and beyond. Comparative Political Studies 43(8-9):931-968.

Carothers, Thomas. 2002. The end of the transition paradigm. Journal of Democracy 13(1):5-21.

Central Intelligence Agency. 2019. The world factbook 2019. https://www.cia.gov/library/publications/ resources/the-world-factbook/index.html. Accessed 20 Dec 2019.

Cheibub, José Antonio. 2007. Presidentialism, parliamentarism and democracy. New York: Cambridge University Press.

Cheibub, José Antonio, Jennifer Gandhi, and James Raymond Vreeland. 2010. Democracy and dictatorship revisited. Public Choice 143(1):67-101.

Coppedge, M., J. Gerring, S. Lindberg, S.-E. Skaaning, J. Teorell, D. Altman, M. Bernhard, M.S. Fish, A. Glynn, A. Hicken, C.H. Knutsen, K. McMann, P. Paxton, D. Pemstein, J. Staton, B. Zimmerman, R. Sigman, F. Andersson, V. Mechkova, and F. Miri. 2015. V-Dem Codebook v5. Varieties of democracy (VDem) project. Gothenburg: V-Dem Institute at Gothenburg University.

Coppedge, Michael, Lucía Tiscornia, and Staffan I. Lindberg. 2016. Varieties of democratic diffusion: colonial networks. Working Papers, Vol. 2016:2. Gothenburg: V-Dem Institute at Gothenburg University.

Darmofal, David. 2015. Spatial analysis for the social sciences. Cambridge: Cambridge University Press.

Denk, Thomas, and Sarah Lehtinen. 2016. Two modes of democratization: transition and state-formation. Quality \& Quantity: International Journal of Methodology 50(6):2331-2346.

Denk, Thomas, and Sarah Lehtinen. 2019. State-formation and democratization: a new classification 1946-2015. Basingstoke: Palgrave Macmillan.

Doorenspleet, Renske. 2005. Democratic transition: exploring the structural sources of the fourth wave. London: Boulder.

Elgie, Robert. 2011. Semi-presidentialism: sub-types and democratic performance. Oxford: Oxford University Press.

Elgie, Robert. 2018. Semi-presidentialism, premier-presidentialism and president-parliamentarism-A new country-years dataset [Blog post, 3 April. http://presidential-power.com/?p=7869. Accessed 8 Aug 2019.

Frye, Timothy. 1997. A politics of institutional choice: Post-communist presidencies. Comparative Political Studies 30(5):523-552.

Gassebner, Martin, Michael J. Lamla, and James Raymond Vreeland. 2013. Extreme bounds of democracy. The Journal of Conflict Resolution 57(2):171-197.

Geddes, Barbara. 1996. Initiating of new democratic institutions in Eastern Europe and Latin America. In Institutional design in new democracies: Eastern Europe and Latin America, ed. Arend Lijphart, Carlos H. Waisman, 15-41. Boulder: Westview.

Gleditsch, Kristian Skrede, and Michael D. Ward. 2006. Diffusion and the international context of democratization. International Organization 60(4):911-933.

Goldring, Edward, and Sheena C. Greitens. 2019. Rethinking Democratic Diffusion: Bringing Regime Type Back in. Comparative Political Studies 53(2):319-353.

Gunitsky, Seva. 2014. From shocks to waves: hegemonic transitions and democratization in the twentieth century. International Organization 68(3):561-597.

Hedström, P. 2010. Studying mechanisms to strengthen causal inferences in quantitative research. In The oxford handbook of political methodology, ed. D. Collier, J.M. Box-Steffensmeier, and H.E. Brady, 319-335. Oxford: Oxford University Press.

Houle, Christian, Mark A. Kayser, and Jun Xiang. 2015. Diffusion or confusion? Clustered shocks and the conditional diffusion of democracy. International Organization 70(3):687-726.

Huntington, Samuel P. 1991. The third wave: Democratization in the late twentieth century. Norman: University of Oklahoma Press. 
Jung, Jai Kwan, and Christopher J. Deering. 2015. Constitutional choices: Uncertainty and institutional design in democratizing nations. International Political Science Review 36(1):60-77.

Kopstein, Jeffrey S., and David A. Reilly. 2000. Geographic diffusion and the transformation of the postcommunist world. World Politics 53(1):1-37.

Leeson, Peter T., and Andrea M. Dean. 2009. The democratic domino theory: an empirical investigation. American Journal of Political Science 53(3):533-551.

Lewis-Beck, Michael S. 1993. Regression analysis. London: SAGE.

Lijphart, Arend. 1990. The Southern European examples of democratization: six lessons for Latin America. Government and Opposition 25(1):68-84.

Lijphart, Arend. 1992. Democratization and constitutional choices in Czecho-Slovakia, Hungary and Poland 1989-91. Journal of Theoretical Politics 4(2):207-223.

Linz, Juan J. 1990. The perils of presidentialism. Journal of Democracy 1(1):51-69.

Linz, Juan J. 1994. Presidential or parliamentary democracy: Does it make a differences? In The failure of presidential democracy, ed. Juan J. Linz, Arturo Valenzuela, 3-87. Baltimore: Johns Hopkins University Press.

Linz, Juan J., and Alfred Stepan. 1996. Problems of democratic transition and consolidation. Southern Europe, South America, and post-communist europe. Baltimore: Johns Hopkins University Press.

Maggetti, Martino, and Fabrizio Gilardi. 2016. Problems (and solutions) in the measurement of policy diffusion mechanisms. Journal of Public Policy 36(1):87-107.

Mainwaring, Scott. 1993. Presidentialism, multipartism and democracy: the difficult combination. Comparative Political Studies 26(2):198-228.

Mainwaring, Scott, and Martin S. Shugart. 1997. Presidentialism and democracy in Latin America. Cambridge: Cambridge University Press.

Maoz, Zeev, and Errol A. Henderson. 2013. The world religion dataset, 1945-2010: logic, estimates, and trends. International Interactions 39(3):265-291.

Melitz, Jacques. 2008. Language and foreign trade. European Economic Review 52(4):667-699.

Møller, Jørgen. 2013. When one might not see the wood for the trees: the 'historical turn' in democratization studies, critical junctures, and cross-case comparisons. Democratization 20(4):693-715.

O'Loughlin, John, Michael D. Ward, Corey L. Lofdahl, Jordin S. Cohen, David S. Brown, David Reilly, Kristian S. Gleditsch, and Michael Shin. 1998. The diffusion of democracy, 1946-1994. Annals of the Association of American Geographers 88(4):545-574.

Pop-Eleches, Grigore. 2007. Historical Legacies and Post-Communist Regime Change. The Journal of Politics 69(4):908-926.

Power, Timothy J., and Mark J. Gasiorowski. 1997. Institutional design and democratic consolidation in the third world. Comparative Political Studies 30(2):123-155.

Rogers, Everett M. 2005. Diffusion of Innovations. New York: Free Press.

Rost, Nicolas, and John A. Booth. 2008. Determinants of regime type in newly independent states. European Journal of Political Research 47(6):635-664.

Sartori, Giovanni. 1997. Comparative constitutional engineering. New York: New York University Press.

Simmon, Beth A., Frank Dobbin, and Geoffrey Garrett. 2006. Introduction: The international diffusion of liberalism. International Organization 60(4):781-810.

Simpser, Alberto, Dan Slater, and Jason Wittenberg. 2018. Dead but not Gone: Contemporary Legacies of Communism, Imperialism and Authoritarianism. Annual Political Science Review 21:419-439.

Singer, J. David. 1987. Reconstructing the correlates of war dataset on material capabilities of states, 1816-1985. International Interactions 14(2):115-132.

Starr, Harvey. 1991. Democratic dominoes: Diffusion approaches to the spread of democracy in the international system. Journal of Conflict Resolution 35(2):356-381.

Starr, Harvey, and Christina Lindborg. 2003. Democratic dominoes revisited: The hazards of governmental transitions, 1974-1996. Journal of Conflict Resolution 47(4):490-519.

Stinnett, Douglas M., Jaroslav Tir, Paul F. Diehl, Philip Schafer, and Charles Gochman. 2002. The correlates of war project direct contiguity data, version 3. Conflict Management and Peace Science 19(2):58-66.

Persson, Torsten, and Guido Tabellini. 2003. The economic effects of constitutions. Cambridge: MIT Press. Teorell, Jan. 2010. Determinants of democratization: Explaining regime change in the world, 1972-2006. Cambridge: Cambridge University Press.

Teorell, Jan, Stefan Dahlberg, Sören Holmberg, Bo Rothstein, Anna Khomenko, and Richard Svensson. 2016. The quality of government standard dataset, version Jan16. University of Gothenburg: The Quality of Government Institute. 
Torfason, Magnus Thor, and Paul Ingram. 2010. The global rise of democracy: a network account. American Sociological Review 75(3):355-377.

Ward, Michael D., and Kristian S. Gleditsch. 2008. Spatial regression models. London: SAGE.

Wejnert, Barbara. 2005. Diffusion, development, and democracy, 1800-1999. American Sociological Review 70(1):53-81.

Wejnert, Barbara. 2014. Diffusion of democracy: The past and future of global democracy. Cambridge: Cambridge University Press.

Weyland, Kurt. 2014. Making waves: Democratic contention in Europe and Latin America since the revolutions of 1848. Cambridge: Cambridge University Press.

Wong, David, and Robert D. Woodberry. 2015. Who is my neighbor? Cultural proximity and the diffusion of democracy. Paper presented at the Annual Meeting of the American Political Science Association, San Francisco, 3 September 2015. 